\title{
Analysis on the Training Mode of Finance Major in Applied Universities from the Perspective of Production
}

\author{
Heng Wang ${ }^{1, a}$
}

\author{
${ }^{1}$ School of Economics, Hubei Business College, Wuhan, Hubei Province, China \\ ${ }^{\mathrm{a}} 14283854 @ \mathrm{qq} . c 0 m$
}

\begin{abstract}
Industry-university-research cooperation education is an important way to cultivate application-oriented undergraduate talents, which is of great significance to the cultivation of students' practical ability, application ability, innovation ability and comprehensive quality.However, from the current situation, there are still many deviations in the mode of industry-university-research cooperation in the aspects of training objectives, personalized needs of students and social needs. From the perspective of finance major and the training goal of industry-university-research cooperation education, this paper discusses the new training of finance major in China's application-oriented universities from the perspective of industry-university-research cooperation. With the popularization of higher education in China, the quality problem of talent training has become increasingly prominent, and has become the focus of social attention. How to train innovative talents and how to improve the quality of the whole higher education system has become an urgent problem to be solved in application-oriented higher undergraduate education.
\end{abstract}

Keywords: industry-university-research cooperation, personnel training mode, application-oriented universities

\section{THE SIGNIFICANCE INDUSTRY-UNIVERSITY-RESEARCH COOPERATION EDUCATION APPLICATION-ORIENTED UNDERGRADUATE CULTIVATION MODEL \\ OF \\ TO \\ TALENT}

The ultimate goal of industry-university-research cooperation is to cultivate talents needed by the society, enhance the social competitiveness and adaptability of graduates, and solve the disconnection between social needs and school education.In order to achieve the integration of industrial development and school education, jointly build a scientific personnel training system, jointly implement the personnel training process, and jointly evaluate the quality standards of personnel training.

\section{OBJECTIVES \\ INDUSTRY-UNIVERSITY-RESEARCH COOPERATION TRAINING FOR FINANCE MAJORS}

\subsection{Cultivate Application-oriented Financial Talents with Strong Practical Ability}

Take trains the student to set up the correct outlook on life and values, to improve students' ability to apply theory and practical analysis of financial problems solving ability, financial practice ability, ability to adapt to the workplace and psychological factors concretely to the whole process of talent training, training professional moral level is high 1], the basic theoretical knowledge and practical ability, strong ability to adapt and self improvement potential larger applied financial talents.

\subsection{Establish a Teaching System in Line with the Training of Application-oriented Financial Talents}

We will deepen the reform of the training model of application-oriented financial personnel, strengthen the construction of professional connotation, and establish a theoretical teaching system in line with the training of application-oriented financial personnel.

\subsection{Establish a Team of High-quality "Double-qualified and Double-capable" Finance Teachers}

Based on the principle of combining independent cultivation and foreign introduction, we should establish and improve the long-term mechanism for the rapid growth of excellent talents and optimize the structure of teachers majoring in finance. Efforts to build a noble teacher ethics, good quality, rational structure, full of vitality and combination of "double teachers and double ability" teachers 2]. 
3.2. Improve the Teaching Content and

3. CONTENT AND IMPLEMENTATION $\begin{array}{llr}\text { PATH OF THE } & \text { COOPERATION } \\ \text { CONSTRUCTION } & \text { OF } & \text { FINANCE } \\ \text { PROFESSIONAL INDUSTRIAL RESEARCH }\end{array}$

To apply the technical personnel training as the center, to care for students' future development as the main line, with profound cooperation, build collaborative innovation platform as the main path, the professional course system, teaching content, teaching mode and so on carries on the demand conduction type reform, innovation of applied finance undergraduate talents training mode and system, speed up the finance from ordinary bachelor degree to the application of technical transformation, comprehensive improve the ability of finance professionals to adapt to changes in human resources market, improve the service ability of regional economic and social development[3].

\subsection{Deepen the Reform of Application-oriented Personnel Training Model}

\subsubsection{Cultivate New Financial Professional Direction}

According to the requirements of the "public entrepreneurship, peoples innovation", especially in the Yangtze river economic belt development demand for financial education to further strengthen and finance related industries and development trend of talent demand research, on the basis of finance professional construction achievements, foster 2-3 local industry oriented new finance professional direction, such as credit management, risk management, financial services, international monetary and financial and other professional direction[4].

\subsubsection{Construct a Modern Teaching Model Centered on "Learning for Application"}

Closely linked to economic and social development, especially the demand for financial education development of the Yangtze river economic zone, according to the requirements of the financial deepening reform and further opening, combined with the new trend of finance professional development at home and abroad, actively explore the quality standards of popularization of higher education entered the stage, further study of social and economic development of financial talent demand trends, in order to cultivate students' innovative spirit and practical ability as the starting point, to the sustainable development of the students as the basic requirements and application-oriented talents training target, construction of "knowledge" as the center of the modern teaching mode[5].

\section{Curriculum System of Application-oriented Financial Talents Training}

\subsubsection{Strengthening the Construction of Specialized Courses}

Construct scientific professional curriculum system. Through in-depth investigation and research, actively absorb the opinions and Suggestions of relevant experts in the financial field, straighten out and optimize the overall structure of the course, review and integrate the existing course setting, enrich new contents such as Internet finance, so as to build a scientific and reasonable professional course system. In the course construction system, we should lay a solid theoretical foundation to meet the needs of students' self-improvement. Strengthen the practice teaching link; Reflect new achievements of financial theory research and impart the latest knowledge; Reflect the new development of financial practice and adapt to the needs of employers; Enhance students' ability to adapt to their major; Attach importance to the cultivation of financial literacy, so that students have good professional ethics and correct professional thinking.

\subsubsection{Attach Importance to the Cultivation of Financial Literacy}

Through the school's existing financial association to actively develop financial literacy training. Through various financial skills competitions, financial entrepreneurship programs, social practice and other cultural and sports activities, lectures and other activities, students are trained to have good professional ethics, correct and firm professional ideas, and love financial work.

\subsection{Strengthen the Construction of Double-qualified and Double-capable Teachers}

\subsubsection{Optimize the Structure of Teaching Staff}

First, according to the needs of professional development, we should pay attention to the introduction of teachers with high academic level, certain popularity and social influence, good development prospects and leading qualifications in the field of finance. In terms of talent introduction, it is necessary to strengthen the introduction of professional leaders who grasp the direction of professional reform and development, grasp the frontier of disciplines and master the working procedures of industrial enterprises. Continue to introduce backbone teachers with working experience in financial enterprises and practical teaching ability to improve the structure of the existing teaching team; According to the needs of professional development, we introduce some young teachers with advanced education in each year. 
training, scientific research and technical services.

\subsubsection{Improve the Overall Quality of the Finance Teaching Team}

Improve the professional teachers' practical teaching ability, strengthen the teachers guide students to discover, analyze and solve problem ability, project construction period send two to three young and middle-aged backbone teachers every year to one's credentials the exercise of financial companies, engaged in financial practices associated with this professional work, to the actual work experience, understand and grasp the dynamic financial practice, promote teachers' teaching and scientific research ability.

\section{STRENGTHEN THE CONSTRUCTION OF PRACTICAL TEACHING}

\subsection{To Build a Financial Simulation Experiment Training Center with Financial Characteristics in Hubei Province}

Oriented by the demand for financial application-oriented talents serving the "Yangtze river economic belt", it aims to meet the demand of the financial practice field for the production, study and research of colleges and universities in the future. The construction of experimental teaching content system, experimental teaching team, laboratory opening, laboratory management and equipment conditions has reached the advanced level of similar universities in hubei province.

\subsection{To Build a Provincial "Integrated Demonstration and Training Center of Application-oriented Finance"}

Guided by the demand for financial talents serving the "Yangtze river economic belt", and based on meeting the practical needs of future financial teaching and improving teachers' teaching and scientific research level, it follows the internal rules of financial experimental teaching and becomes an important base for the cultivation of applied financial talents in hubei province.

\section{ENHANCE THE ABILITY AND LEVEL OF SERVING THE SOCIETY}

We will adhere to the path of industry-university-research cooperation in running schools, commit ourselves to financial innovation, and improve the level of applied scientific research and management services for local economy. According to the actual needs of social and financial enterprise development, we will actively strive for the qualification of financial practitioners training institutions in local areas, encourage finance professional teachers to obtain the qualification of training teachers, and conduct training and qualification examination for financial practitioners in local financial institutions. Through school-enterprise cooperation, school-local cooperation and other ways, with the purpose of serving local areas, financial enterprises and society to vigorously carry out management consulting, vocational

\section{STRENGTHEN EXCHANGES AND COOPERATION AMONG DOMESTIC COLLEGES AND UNIVERSITIES}

Strengthen the mutual communication among teachers of similar schools and promote the rapid development of majors. Teachers are selected to study and communicate with universities at home and abroad, and some well-known experts and scholars are invited to give special lectures regularly, so that teachers can master the frontier trends of this subject. Strengthen exchanges and cooperation with other colleges and universities to improve the level of professional cooperation. At the same time, strengthen the cooperation with Shanghai university of finance and economics, central university of finance and economics, southwest university of finance and economics and other well-known domestic universities of finance and economics, learn their advanced teaching methods and means; Deepen cooperation with banking, securities, insurance and other financial departments.

\section{REFERENCES}

[1] Duan Chunli. Research on the innovation of production-university-research cooperation education mode in local colleges and universities [J]. Modern trade industry, 2008,39(34):145-147.

[2] Yu Honghui. Reform and practice of innovative talent cultivation in application-oriented undergraduate universities [J]. Road to success, 2018(30):1-2.

[3] Wang Yuxing. Research on talent cultivation mode under the mode of "production, study, research and application" [J]. Comparative research on cultural innovation, 2012,2(29):105+107.

[4] Chen Xingwen, wang xiaohua, wang qingchun, an hongda. Research on the construction of curriculum system under the mode of industry-university-research cooperative education in application-oriented undergraduate universities [J]. Education and teaching BBS,2018(37):183-185.

[5] Chen Xingwen, wang xiaohua, wang qingchun, liu yan. Research on cooperative training mode of applied talents based on industry-university-research cooperation education [J]. Education teaching BBS,2018(36):76-78. 